\title{
Abortion from a Bioethical Viewpoint: Autonomy and Beneficency versus Justice?
}

Francisco Javier León Correa*

Bioethics Center, School of Medicine, Pontificia Universidad Católica de Chile, Chile

\begin{abstract}
In this reflection on abortion, we will analyze from the bioethics viewpoint the concept of autonomy; in accordance with the liberal individual model and personal ambitions to be applied to the woman's and the doctor's decision making and the society in general. Now that the abortion liberalization is being proposed in Spain through a law that intends to substitute the decriminalization of certain assumptions that have been in effect since 1985 , it is necessary to analyze in deep the ethical aspects beyond the legal and social approaches. Bioethics and Law must join together, since both have the same aim: the promotion of human life respect and its basic rights; safeguard -as long as possible -, the values within an interpersonal relationship that lead to fulfill a woman's life having an unwanted pregnancy, as well as that of the fetus and the doctor; and always trying to protect the rights of those who are the weakest: the woman and the fetus, without disregarding everyone's duties with them.
\end{abstract}

Keywords: Abortion; Bioethics; Autonomy

\section{Introduction}

Before starting to discuss about decisions relating to abortion, which may be dealt with from very different perspectives, e.g., social, psychological, medical, legal, ethical, etc., in bioethics we must address two concepts that are extensively used in all debates on this issue, and which give rise to some questions:

1. Statute of human embryo: what or who are the embryo and the fetus? Who are talking about when discussion on abortion? The debate on the statute of human embryo then leads us to related question: When does human life start? Is it a matter to be determined by philosophy or science? Or, perhaps, by both?

2. Woman's autonomy to decide: What is autonomy? What are its limits, if any? Can the mother - or other people, including the physician - decide for the fetus? and finally, can the mother - or other people - including the physician, carry out a deeply malicious action, as is abortion, on the fetus, by charitable reasons for the mother?

Perhaps these are the most fundamental questions on abortion that are raised in all debates from different bioethical perspectives, although they are certainly not the only ones. We will not deal with the former one, since it corresponds, rather, to the debate on in-vitro fertilization and assisted reproduction, whereby embryos are manipulated [1]. Suffice it to say that some sustain- with little substantiation, in our opinion - a differentiated ethical respect, and the difference would lie in biological development, for example, and thus we would be able to "handle blastocytes, take care of embryos, and respect fetuses", as is proposed, although "merely as argued and arguable material" [2]. In any case, there is no doubt about the "superior dignity" attributed by all to the fetus. We will only sustain that science's effort must be joined, which increasingly uncovers for us the genetic mysteries of the embryo prior to implantation, with those of philosophy and law.

We will briefly review the concept of human being's dignity, as well as that of the fetus, based on the philosophical reflection of conviction, that of responsibility, and that of compassion, and then we will deal with the ethical duties towards the human being in the fetal status, which is precisely what we mean when dealing with voluntary abortion.

\section{Human Dignity from Conviction, Responsibility and Compassion}

The description of human being as an individual of a species whose nature corresponds to that of a living being having rational power, already implies a value judgment. We regard the human being as a good that we place above everything else, and we state that the human being has dignity, not a price. This implies a value judgment in the form or a final practical judgment on which we all agree with. With this, we do not restrict ourselves to the features described by biology, but attribute to human beings, as apposed to other living beings, an absolute, or at least greater, value, since human beings are living beings whose nature is to be endowed with rational power, to be able to relate to others of his/her kind, and to pursue their own objectives.

We say, therefore, that all human beings have dignity, and most of us also recognize, as a result, that human life is sacred. This view, in essence, means that human life possesses value that does not depend on any other consideration, such as interests or rights, social relations or communicative competence. "Almost everyone shares, explicitly or intuitively, the idea that human lives has objective and intrinsic value which is completely independent of personal valuation that anyone makes of it "[3]. It is only by assuming the general acceptance of this premise that it is possible, according to Dworkin, to understand why abortion is still a problem for those who regard the embryo as a person, or the problem resulting from the euthanasia dilemma, even when required by the affected person.

Although the idea of life inviolability, from its inception, is more declared in he context of religious convictions, such is the belief that

*Corresponding author: Francisco Javier León Correa, Associate Professor, Bioethics Center, School of Medicine, Pontificia Universidad Católica de Chile, Centro de Bioética, Alameda 340, Santiago de Chile, Chile, Tel: 562-23543048. Fax: 562-26339785; E-mail: gibioetica@vtr.net

Received May 03, 2013; Accepted July 29, 2013; Published July 31, 2013

Citation: León Correa FJ (2013) Abortion from a Bioethical Viewpoint: Autonomy and Beneficency versus Justice? J Clin Res Bioeth 4: 151. doi:10.4172/21559627.1000151

Copyright: (c) 2013 León Correa FJ. This is an open-access article distributed under the terms of the Creative Commons Attribution License, which permits unrestricted use, distribution, and reproduction in any medium, provided the original author and source are credited. 
every human being is a God's creature, as regards the protection of human life of the unborn or of those who are dying, said conviction is also shared by a fair number of individuals who do not believe in God and, therefore, it may be concluded that it is not forcibly linked to religious premises.

But the general sense of esteem of human dignity appears to be conflictive in the debate on abortion: human dignity- in this case, of the woman facing an unwanted pregnancy - may be understood as freedom, as regards legal dignity, and, therefore, as autonomy. Unwanted pregnancy would be, consequently, a serious limitation of autonomy and of woman's fulfillment and life plans. The dignity of the fetus would be a "consensus" dignity, according to the prevailing criteria in society or of the people involved in their care, from a strictly secular, not religious, vision [4]. This is the vision that lies on the foundations of different positions favorable to the legal liberalization or decriminalization of abortion in most countries. We will soon review it herein below, after briefly reviewing some other conceptions of dignity.

The "ontological dignity" concept may be regarded, from the ethics of conviction, as the "specific category that a human being that claims - to himself and to others - esteem, custody and fulfillment" [5]. "All forms of dignity are in the first source, purely ontological dignity... When depriving the unborn and the other human persons of their life, we also deprive them of the possibility to reach that deeper dimension of their vocation to reach a dignity deeper than that of mere living persons" [6].

Or, further, not as an anthropological but ethical principle, "dignity as an irrefutable a priori", in the content of the Kant principle of never treat a man only as a means but also as an end.

From responsibility, we see that dignity as an ethical duty of care. Hans Jonas, referring to life in general, and also about human life, speaks of fear of the disappearance of a valuable, but vulnerable and defenseless being, which incites us to take responsibility for him, if we can protect him [7]. The symmetry or asymmetry relationship does not matter, but "responsibility, which is not a legal, but a biological relationship: with the newly born those who have power to protect him feel responsible ... the human being lives taking care of what requires care, in this case, Earth and the vulnerable species" [8].

From compassion, we perceive dignity fundamentally as vulnerability.

In Levinas, the face of the other, of the child, is what creates the desire of compassion, recognition and duty of care for him: "The absolute nudity of the face, this completely defenseless face without coverage, undress, without a mask, is, however, what opposes my power over him, my violence, what fully opposes it" [9]. It is the experience of this call what substantiates our ethical response: compassion is the authentically "human" answer to vulnerability [5].

\section{Woman's Autonomy: Can the Mother Decide for the Fetus?}

There is a wide variety of conceptions and assessments regarding the principle of autonomy and its scope within clinical ethics, in health care. It is a widely used term in the field of law, but our present interest is in an ethical analysis to further know what philosophy can teach us about autonomy [10]

We come across the assertion of a radical autonomy in numerous authors, especially in the Anglo-Saxon world. Autonomy is regarded as a possession of the individual who decides upon himself with full independence, according to Stuart Mill, who, in its renown book "About Freedom", wrote: "No man can, fair and square, be forced to act or to abstain from doing so, because out of that acting or abstention may arise a good for him, because that will make him happier, or because, in the others' opinion, doing so is sensible or fair. These are good reasons for discussing with him, to convince him or to beg him, but not to force him or harm him if his acts differently as we wish. For this coercion to be unjustified, this person's conduct would have to be aimed at harming the other man. For anything that is not anybody's business but his, his independence is, in fact, absolute. The individual has sovereignty on himself, his body and spirit." [11].

But, in practice, very often we face patients with no or reduced competence who hinder the immediate application of Stuart Mill's principle, even if agreeing with them, forcing us to make surrogated decisions, each time farther from that "individual sovereignty". In addition, in the Latin American scope, family plays an important role in clinical decisions and in informed consent, in face of the most extremist individualism. This takes place in a more complex fashion as for woman's decisions on abortion, due to pressure from her partner, her parents when a minor, social rejection to unwed mothers, etc. And, also, due to that patient's independence to decide, very often we see situations of situations of economic inequalities, instances of injustice as to equal access to health care, large differences between public and private health care, and significant inequalities between well-informed patients and others with low health education.

This also causes, on occasions, favorable arguments for the legalization of abortion, for the disappearance of social differences between rich and poor. In fact, two models coexist in our countries: that with private health care, and that with public health care. But we cannot keep the idea that private one would be the scope of the patient wishing to be autonomous, whereas the public one remains - in fact, no it the theoretical rights - as the field of charity and justice. This position would be radically unfair. All patients are autonomous, both rich and poor, but the question is: how far does the autonomy of the patient, rich or poor, go from the ethical viewpoint?

Autonomy is a concept that was introduced to ethics by Kant [12]. It etymologically refers to the capacity to create the laws himself. In Kantian ethics, autonomy has a formal sense, meaning that moral rules are inherent to the human being for his own reasoning and not by any instance external to him. In bioethics, this term has a more concrete meaning and some - especially in the Anglo-Saxon world define it as: the capacity to make decisions, free of coercion as regards the individual's own body and health care, and about life and death $[13,14]$. But this conception of autonomy is quite poor, since, without any other referent than free decision, when we have the experience, all who can autonomously decide on something that is not convenient to us, something that later causes us regret and which goes against our most fundamental principles. Autonomy is an expression of the dignity of the human individual, of all human beings, and is deeply linked to the individual's freedom-dignity relationship [15]

The present problem, which some American authors are now trying to solve, is to balance, in the bioethical analysis, the principles of autonomy with those of justice and beneficency in a system that has unilaterally favored patient's autonomy, which has led to a defensive Medicine contrary to the interests of the physicians and the patients themselves. What is sought now is a "non-paternalist beneficency" that may sustain a more humanized health care system, and a kind of medicine not only being at the defensive regarding patients' increasing and more demanding rights. In a recent book, Alfred Tauber, a 
physician and philosopher, analyzes how the principle of patient's autonomy - strongly demanded in contemporary society - must be related to (non-paternalist) beneficency and responsibility: beneficency and responsibility are moral principles not only compatible with patient's autonomy, but closely tied to it [16].

In short, the abortion question in not only a topic on the mother's autonomy, but also one that relates to the crash between said autonomy and due beneficency to the fetus as a human being, whose dignity must be respected.

Autonomy, therefore, is not unlimited; it is part of the responsible freedom of the human being who knows that he must act respecting the freedom of others, even if that restricts him or causes him a problem, and who also knows that he must act in accordance with his own dignity as a person. This morally forces him to take care for and respect the basic goods comprising his dignity: life, health, his own conscience and that of the others.

Summing up, a free action by a mother who is aborting her own fetus not only is causing tremendous damage to the fetus, depriving it of the greatest good that there is, life, but is also causing an irreparable loss to her own moral dignity as a person. And, is said regard, great responsibility is held by those who provide help for or promote that "solution" to unwanted pregnancy. Solutions respecting the dignity of all the individuals involved in the decision, where the unborn must also be included, must be found [1].

\section{Human Dignity, Ethics and Human Rights}

Human dignity is the dignity of a being that is an end to himself in itself, for being a person. Personality is something essential to man, not a mere feature that is acquired, that is had for being a man [17]. Due to this, it is the only possible basis for a deep foundation of human rights. In the root is dignity of the human being, as well as his freedom. The dignity of both woman and fetus is at stake in the moral decisions to abort. So is the fundamental human right to life, which is held by all human beings. It is not a positive right; we do not have the right to live, so that we could "demand" others to keep us alive, but it is a negative right: the right for no one to attempt against our life, the right for our life not to be taken unjustly. And that is the right of the fetus. And we do not have the fundamental human rights - the right to life, to health, to freedom of conscience - , because others or society agree that we have them. The others and society must respect them and also promote their being respected, precisely for being the expression of what is valuable and transcending of each human life and first expression of its dignity [18].

Ss for human life in embryonic or fetal state, the potential of being or not being cannot be mistaken. The embryo and the fetus already have human quality; they are human beings with the potential to develop all those characteristics defining, when mature, a person. That potential is power, not negation of the being: it has human dignity for the fact of being "already a human ". "There is permanence, without a doubt, - comments Juliana González- and in this sense, "being": but what remains in snot something, other than the change itself. It is reality itself which remains and changes, the former for the latter. Hence, it is rather "ownliness" than identity" [19]. Although this author is favorably incline to research with embryos, she speaks of due respect to the fetal being, the "same" but not "identical", though, to the newly born: the embryo and the fetus are, in effect, at a stage or temporary phase especially defined by potentiality, but they are human embryo and fetus, possessing the genetic heritage that is distinctive of the human species and of their own original singularity or uniqueness, nothing can reduce its human life significance. Thence, they deserve special "respect" and humanizing treatment [19].

This also works in the entire scope of bioethics in pediatrics, where there is not a complete development of the being's potentialities, either. It also works when the fetus shows deficiencies, genetic anomalies or diseases that will irremissibly lead to death. It is not reasonable for us to decide, from the outside, that said fetus is not going to have "sufficient quality of life", since this is a subjective appreciation that cannot get universalized: each one of us has a notion of what we believe is quality in our lives.

\section{Physician's Autonomy: Can the Physician Decide for the Fetus?}

Irrespective of what is provided by the laws of each country, whether voluntary abortion is legalized or decriminalized or not, it must be taken into account that not all that is legally allowed is ethically correct. It may be that some legislations do not decriminalize abortion under certain circumstances, but that not turn it, in itself, something morally acceptable.

Neither do we indicate here what would be the social solutions to such issues as teen pregnancy, illegal abortions, and others. The solution offered by some to these social dramas is the legalization of artificial abortion, or, at least, its decriminalization [20], without considering that, in itself, abortion is a drama that adds to the former ones [21] and that any solution must be based on education for responsible parenthood, beyond the demand of some reproductive rights that would include abortion [22].

There certainly is social pressure upon physicians for their performing legally approved abortions, even within the public health care system itself, as happens in some countries. In view of this, we must take into account the generalized stance of most of medical associations against it, and the ethical demands for protection of unborn human life that are expressly written in some Deontological Codes.

The World Medical Association, in a declaration on therapeutic abortion, states [22]:

1. The first moral principle imposed upon the physician is respect of human life from its inception.

2. The circumstances that place the mother's vital interests in conflict with the vital interests of the being that about to be born, create a dilemma and raise a question on whether pregnancy must be deliberately interrupted or otherwise.

3. The diverse answers to this situation arise from the plurality of attitudes towards the life of the being soon to be born. This is a matter of individual conviction and conscience that must be respected.

4. It is not fie the medical profession to determine the attitudes and rules of a particular nation or community regarding this matter, but it is its duty to guarantee protection of its patients and defend the rights of the physician within society.

5. Therefore, where therapeutic abortion is allowed by law, the procedure must be performed by a qualified physician in a place authorized by the appropriate authorities.

6. Should a physician believe that his/her convictions do not allow him/her to advice on or perform an abortion, he/she may step aside, provided it is guaranteed that a qualified colleague will continue to provide medical attention. 
The Deontological Code of the Spanish Medical Association, in a chapter on human reproduction, reads (Article 24. 1): "A sick human embryo must be treated in accordance with the same ethical guidelines, including the informed consent of its progenitors as applied to all other patients".

These texts clearly indicate the legal field of the physician's action, as well as that for his/her ethical abstention, and respecting the right to conscientious objection of health professionals. We would state, as a summary of the deontological doctrine generally accepted in most of our countries [23], as follows:

a. A physician can never kill by action or inaction: This, which applies to euthanasia, also applies to artificial abortion which is a serious ethical and deontological fault.

b. A physician cannot start futile and hopeless treatments. Therapeutic obstinacy - although they can sometimes request it from parents or relatives - is an ethical mistake and lack of competence and this is also valid to set limits via a principle of proportionality as to the limits of the medical therapeutic intervention on the fetus during pregnancy.

c. Parents, especially the pregnant mother, has an ethical duty to preserve the life of their child and to accept the treatments aimed to save it, if they refer to means offering reasonable hope of benefit and which can be obtained and applied without any major inconveniences, pain or spending.

d. Nowadays, the discussion on abortion is no longer focused on the classic problem of whether or not the embryo is a human being. Its center of gravity has moved towards the question, raised by the most extreme liberalism advocating the mother's presumed right to abort, based o her moral autonomy, irrespective of data on embryology and the anthropological reflection on the embryo. That is why the limits imposed by moral dignity to the mother's decision, and to that of relatives and the treating physician, must be underlined, if they really wish to respect the right to life of the unborn.

e. And, finally, it must not be forgotten that the Code of Ethics of the Chilean Association of Physicians, $8^{\text {th }}$ article, provides that "the respect for human life from its inception and to its end, constitutes the basic foundation of the physician's medical practice. Any medical intervention performed during the nine months of pregnancy shall always watch for the best interest of the mother and of the child" [24].

\section{Principles of Bioethics: Autonomy or Beneficency against Justice in Abortion?}

We already have a fair number of references to be able to understand why the argument of the confrontation of principles in bioethics, between the mother's autonomy and her beneficency, and the maleficency that is done with the aborted fetus, is no longer valid. But before addressing this, with would like to clarify that an abortion is never an act of beneficency to the mother, either, since it breaks any proposed ethical ideal of happy life, as defined by Paul Ricoeur: the desire of a fulfilled - and, as such, happy - life, with and for others, on fair institutions [25].

We will review the relationships between autonomy, beneficency and justice, just as they are presented in decisions on voluntary abortion.

We all exercise our freedom in the outlook of the good life we intend to lead, in the outlook that ideals give us. Moral life intends to fully realize our potentials and life projects. That is why unwanted pregnancy may first present itself as a strong restrain to freedom. All of us, but especially women facing unwanted pregnancy, must re-write quite often in our life those outlooks and ideals, although we may keep them as ends. We all have limitations, and there are times when they express themselves more strongly. And we all deal with then with the help of others, not alone. The woman facing an unwanted pregnancy must be helped by her physician and all the professionals involved, by her partner, her parents, and the entire society, which shall somehow take over if the others fail.

But, what is a fulfilled, achieved life? We may state what a life that reaches levels of excellence outside the individual is: he scientific genius, the rich entrepreneur, the successful physician, the elite sportsman, the independent and successful actress, fully fulfill their lives in that aspect of their activities, but this does not mean that these lives are accomplished in every aspect, in their family relations, in their affections, ideals, etc. It is true that in the case of the woman facing an unwanted pregnancy, this level of external excellence may be deeply affected, in both the present and future, and half fulfilled.

But, a deeper answer, from a proper moral sense, perhaps, would be that a fulfilled life is that where there is agreement between what we end up doing and being, and the ideals that we mark from the potentials we have, including the personal ones and those freely provided by others. This would be a fulfilled life with internal levels of excellence, and all of us are called to this self-fulfillment, including the woman who is facing an unwanted pregnancy.

Thus, autonomy would be, according to Ricoeur, the deontological face of self-esteem that materializes in a fulfillment outlook. The desire for happiness is passed through the regulatory sieve. Not only is a mere desire, because the law must be considered, but there is not any negation of self-esteem either, because the law we must comply with is provided by ourselves, guided by its own reasonable universality.

We all are called to live our own life with an autonomy from which we deal with ourselves, with responsibility. All ethical individuals are subjects with responsibilities, who must make decisions on adequate criteria and answer for the consequences of their own actions. Otherwise, it would be an expression of paternalism that degrades, one that does not recognize the dignity of others.

Our autonomous, fulfillment projects are not strictly individual, or more precisely, individualistic. Opening to others is precisely what makes us morally and allows personal realization. The balanced welcome of others, kindness, compassion, respect and recognition of others are essential in our own moral construction. Both the woman facing an unwanted pregnancy and the attending physician should take this into account.

The physician is bound to his/her patient through a professional contract, and within the framework of an institution. The physician is, therefore, an agent acting in what we and Paul Ricoeur agree to call the third level of ethical intent, that of justice. But, in turn, the physician must establish personalized relationships with his/her patients, and that is why his/her actions move on the "with and for the others" second ethical level. He/she cannot overlook justice, but must act with beneficency, from an ethics of virtues helping the other to achieve a fulfilled life to the greatest extent possible.

On the other hand, the woman who is facing an unwanted pregnancy must also consider he fair rights of the unborn. Doing an 
Citation: León Correa FJ (2013) Abortion from a Bioethical Viewpoint: Autonomy and Beneficency versus Justice? J Clin Res Bioeth 4: 151. doi:10.4172/2155-9627.1000151

Page 5 of 6

injustice - disrespect the child's life - supposes a maleficent act on the child and on herself, because it does not either respect her dignity as a person and is, therefore, unfair to herself. This is the deepest root of the great personal unbalance caused by abortion on the woman. Not only the possible remorse from her religious or ideological convictions, but also the true awareness of having done her child and herself an injustice, which affects her dignity as a person.

\section{From a Social Viewpoint}

In a survey carried out in Mexico, in 2001, by Population Council [26], advocates of the legalization of abortion reported very significant results. Although their statistical objectivity, they say that percentage of the general population agreeing on that woman must have access to abortion varies between $80 \%$ and $64 \%$ when woman's health is at serious risk or the pregnancy is the result of a rape. Acceptance falls abruptly from $52 \%$ when "the product has physical or mental birth defects"(sic), when the woman is underage or she so decides $(20 \%)$ or for lack of economic resources (17\%), the lowest acceptance being when the woman is single or in lack of a contraceptive method (11\%).

The decriminalization of abortion enjoys low support in Brazil, Chile, Mexico and Nicaragua, according to a recent Flacso opinion poll [27]: the average support in the four countries amounts to $23.6 \%$. There is greater consensus on the therapeutic abortion, when the mother's life is at risk, with $41.7 \%$ average (it amounts to $65.5 \%$ in Chile).

We can clearly see that where there are serious situations, acceptance is greater, since the goods at stake and confronted are larger; whereas acceptance is quite low in the case of other secondary goods of the woman with respect to the child's life wellness, which, certainly, is not regarded by the population in these countries as a mere "product" - as is called in the Population Council survey, in addition to the unborn's unlikeness to have "birth defects", if it is still inside the mother's uterus.

Another survey answered by physicians provides results that, although very similar, are more extreme. Acceptance ranges between $97 \%$ and $90 \%$ when pregnancy is the result of a rape, puts the woman's life at risk or causes great damage to her health, or when "the product" shows serious genetic or congenital alterations. In all he other cases, the percentage is lower, between $30 \%$ and $4 \%$, when the woman is a minor, economic resources are low, when contraception fails, or the woman is single [28]. It is just fair -and ethically licit - that a physician intervenes when the mother's life is at risk, even when the fetus is aborted at a secondary level and as an unwanted effect. It is two lives that are at stake and the law shall very clearly specify these cases [29], but, as for all the other cases, we will have to take into account everything that ha been already stated on the limits of woman's and physician's autonomy, the dignity of the human life that is about to be born, and justice's duty to protect its life.

Therefore, we must build from the principle of justice, the basis for the principles of autonomy and beneficency. Before woman's and physician's autonomy, and the mother's possible beneficency with abortion are the obligations imposed by the non-maleficency principles - not to harm the fetus -, and that of justice: respect its right to life and health. This is the generally accepted interpretation of the possible prioritization of bioethical principles, within the scope of European and Latin American bioethics [30] that we can so apply in this particular issue of abortion.

It is here where Bioethics and Law join together, since both are after the same objective: promote respect of human life and fundamental rights; safeguard - as much as possible - the values contained in an interpersonal relationship leading the woman who is facing an unwanted pregnancy, the fetus and the physician to a fulfilled life; and guarantee, at all times, the rights of the most vulnerable, the woman and the fetus, without neglecting everyone's obligations with them.

\section{References}

1. León Correa FJ (2007) El diálogo bioético en las técnicas de reproducción asistida. Acta Bioética 13: 161-167.

2. Masiá J (2005) Manejar blastocistos, cuidar embriones, respetar fetos. In Masiá J (Ed.) Ser humano, persona y dignidad. Desclée de Brouwer, Madrid: 323-326.

3. Rakowski E (1994) The sanctity of human life: Life's Dominion: An Argument About Abortion, Euthanasia, and Individual Freedom, by Ronald Dworkin. Yale Law J 103: 2049-2118.

4. Ortiz G (2009) La moralidad del aborto. Siglo XXI, México.

5. Torralba $F$ (2005) Ideas de dignidad: una exploración filosófica. In: Martínez J, Perotin C, Torralba F. Repensar la dignidad humana. Milenio, Lleida.

6. Seifert J (2002) Human dignity. Dimensions and sources in human personality. In: Borobia JJ, Lluch M, Murillo JI, Terrasa E (eds.) Idea cristiana del hombre. EUNSA, Pamplona.

7. Jonas H (1995) El principio responsabilidad. Herder, Barcelona.

8. Cortina A (2005) Educación en valores y responsabilidad cívica. Editorial El Búho, Bogotá.

9. Levinas E (1994) Liberté et commandement. Fata Morgana, París.

10. León Correa FJ (2006) Autonomía y beneficencia en la ética clínica: ni paternalismo ni Medicina defensiva. Biomedicina, Montevideo 2: 257-260.

11. Mill JS (1970) Sobre la libertad. Alianza Editorial, Madrid.

12. Gracia D (2001) La deliberación moral: el método de la ética clínica. Med Clin 117: 18-23.

13. Torralba F (2005) Qué es la dignidad humana. Herder, Barcelona.

14. Charlesworth M (1996) Bioethics in a liberal society. Cambridge University Press.

15. León Correa FJ (1992) Dignidad humana, libertad y bioética. Cuadernos de Bioética 12: 5-22.

16. Tauber Al (2005) Patient Autonomy and the Ethics of Responsibility. MIT Press, Massachusetts.

17. Spaemann R (1992) ¿Todos los hombres son personas? In: Bioética Consideraciones filosófico-teológicas sobre un tema actual. Rialp, Madrid: 71 73.

18. León Correa FJ (2007) Dignidad humana y derechos humanos en Bioética Biomedicina, Montevideo 3: 240-245.

19. González J (2010) Ética y bioética. Bioética Selecciones, Bogotá 16: 50-61.

20. Faúndes A, Barzalato J (2007) El drama del aborto. En busca de un consenso. LOM Ediciones, Santiago.

21. Herrera Rodríguez S (2004) El aborto inducido ¿Víctimas o victimarias? Catalonia, Cátedra UNESCO de Género, Santiago.

22. World Medical Association (1983) Declaration of Oslo on Therapeutic Abortion Adopted by the $24^{\text {th }}$ World Medical Assembly, Oslo, Norway, August 1970 and amended by the 35 $5^{\text {th }}$ World Medical Assembly, Venice, Italy, October 1983.

23. Herranz G (1990) Eutanasia o Medicina. Cuadernos de Bioética 4: 21-23.

24. Código de Ética (2006) Colegio Médico de Chile, Santiago.

25. Ricoeur P (1990) Soi Même Comme un Autre. Editions du Seuil, París.

26. González D, Billings D (2002) El Aborto en México. IPAS, México DF.

27. Dides C, Benavente MC, Sáez I (2010) Estudio de opinión pública sobre aborto. Brasil, Chile, México y Nicaragua. Flacso Chile, Santiago.

28. Encuesta durante Talleres realizados por IPAS en hospitales de varios Estados mexicanos en 2002. En: González D, Billings D (2002) El aborto en México. IPAS, México DF. 
Citation: León Correa FJ (2013) Abortion from a Bioethical Viewpoint: Autonomy and Beneficency versus Justice? J Clin Res Bioeth 4: 151. doi:10.4172/2155-9627.1000151

Page 6 of 6

29. Besio M (2002) Análisis ético sobre las interrupciones del embarazo, el aborto provocado y el aborto terapéutico. Ars Medica, Santiago 6: 83-94.
30. Gracia D (1999) Prólogo. In: Beauchamp T, Childress JF. Principles of biomedical ethics. Masson, Barcelona: 9-15.

This article was originally published in a special issue, Bioethics Abortion

handled by Editor. Antonio G Spagnolo, Catholic University of the

Sacred

Heart, Italy 